\title{
Archaeological Survey of Areas Slated for Modification Laredo International Bridge II City of Laredo, Texas
}

Feris A. Bass, Jr.

Thomas R. Hester

Center for Archaeological Research

Follow this and additional works at: https://scholarworks.sfasu.edu/ita

Part of the American Material Culture Commons, Archaeological Anthropology Commons, Environmental Studies Commons, Other American Studies Commons, Other Arts and Humanities Commons, Other History of Art, Architecture, and Archaeology Commons, and the United States History Commons

Tell us how this article helped you.

This Article is brought to you for free and open access by the Center for Regional Heritage Research at SFA ScholarWorks. It has been accepted for inclusion in Index of Texas Archaeology: Open Access Gray Literature from the Lone Star State by an authorized editor of SFA ScholarWorks. For more information, please contact cdsscholarworks@sfasu.edu. 


\section{Archaeological Survey of Areas Slated for Modification Laredo International Bridge II City of Laredo, Texas}

\section{Creative Commons License}

\section{(c) (1) (8)}

This work is licensed under a Creative Commons Attribution-NonCommercial 4.0 International License 
ARCHAEOLOGICAL SURVEY OF AREAS SLATED FOR MODIFICATION

LAREDO INTERNATTONAI BRIDGE II

CITY OF LAREDO, TEXAS

Feris A. Bass, Jr.

and

Thomas R. Hester

Center for Archaeological Research

The University of Texas at San Antonio

Archileologleal Survey Report No. 14

1975

\section{UTSA - Center for Archaeological Research}




\section{INTRODUCTION}

In September, 1975, personnel of the Center for Archaeological Research, The University of Texas at San Antonio, carried out archaeological survey and assessment of areas slated for modification in the Laredo International Bridge II project. The field work followed standard archaeological procedures and was conducted under the terms of an ordinance (dated August 19, 1975) passed by the City Council of Laredo, Texas. We would like to acknowledge our gratitude to Mr. Paul Garza for his assistance during the archaeological investigations.

SCOPE OF PRESENT SURVEY

The UTSA survey was restricted solely to those portions of the project under the jurisdiction of the City of Laredo. This includes an area fronting on Sta. Ursala Street, and a series of house lots along Sta. Ursala from Water Street to Hidalgo Street. Areas to be modified by the General Services Administration (between Sta. Ursala and San Francisco Streets, and west of Sta. Ursala Street) and by the Texas Highway Department (facing Sta. Ursala between Hidalgo and Farragut Streets, and three blocks to Victoria Street) were not under the aegis of the present survey.

The objective of the survey was to determine the existence of any archaeological or historical resources; to record, identify and appraise the significance of such resources; to evaluate the impact of the proposed construction project on each of these resources; and, to provide recommendations for the mitigation of any adverse impacts.

Prior to initiating the survey, a check was made of records on file at the Texas Archeological Research Laboratory, Austin. It was determined that 
no archaeological sites had been docunented in the immediate project area.

\section{HISTORICAL BACKGROUND}

The City of Laredo is located on the Rio Grande in south western Webb County, southern Texas. We present here a very brief sketch of some of the early history of the project locality; additional information on the history of Laredo may be found by consulting Bolton (1915), Walsh (1935), Wilcox (1938), De Camara (1942), Webb et al. (1952: 28), Vigness (1948), Benavides (1952), Horgan (1954), and Garcia (1970).

The original site of Laredo was settled by Tomás Sánchez de la Barrera y Gallardo in 1755. Sanchez was operating under the direction of José de Escandon, who had been commissioned by the Viceroy of New Spain to colonize the area in the northeast part of the vice-regency. Sanchez was allotted 15 leagues of land for his settlement on the north bank of the Rio Grande. A mission was established in 1762 and at that time the settlement was designated San Agustin de Laredo; in 1767, San Agustin Plaza was laid out. The population of the original settlement was 13 families. By 1757, there were 85 inhabitants of the village; by 1789 , there were 700 , and in 1835 , the population had reached 1700 .

San Agustin Plaza was the center of the settlement's activity during most of the eighteenth and nineteenth centuries. It was on this site that the capitol building of the Republic of the RLo Grande was established in 1839. This building still stands on the southern border of the plaza.

ARCHAEOLOGICAL BACKGROUND

There has been relatively little archaeological research in the Laredo and Webb County region. Most studies to date have consisted of surface 
surveys involving prehistoric sites (of. Shiner 1969; Hall 1973), dating from Paleo-Indian times (ca. 8000 B.C.; cf. Hester 1974; Mitchell 1974) through the rest of the prehistoric era. However, most of the prehistoric occupation localities in the area have never been properly documented or recorded.

There are also numerous historic archaeological sites in and around the City of Laredo. One interesting example is site $41 \mathrm{WB} 9$, located along Chacon Creek. A series of kiln-like structures have been recorded at this site (Peavy 1971; Hil1 1971).

In 1973, the Texas Historical Commission nominated the San Agustin de Laredo area to the National Register of Historic Places. This is located in the central business district of Laredo (see Fig. 1). Among the significant structures in the district are the capitol of the Republic of the Rio Grande, San Agustin Roman Catholic Church, the Cayetano de 1a Garza home, the Casa Vidaurri, and others.

While the Laredo area is still inadequately known from an archaeological standpoint, there is sufficient evidence to indicate that a wealth of prehistoric and historic archaeological resources are to be expected. Such resources must be considered during the present project and any future developments.

\section{THE SURVEY}

The site for the proposed construction in connection with the new international bridge is located one block east of the rear of San Agustin Cathedral and two blocks east of San Agustin Plaza. The portion of the project which is of concern to the City of Laredo extends along Sta. Ursala Street from Hidalgo Street south to the Rio Grande. The width of the project varies from 
112 feet to 31.4 Eect in that portion letween llidalgo and Zaragoza Strects. South of Zaragoza Street and extending to the river, the width of the project encompasses two blocks except in the block south of Zaragoza and east of San Dario Streets in which only the western four lots are involved.

A thorough examination was made by walking over the area and, where possible, by visiting with occupants of the land and buildings in question. Contact was also made with members of the City of Laredo Historical Commission and the Webb County Historical Society.

RESULTS OF THE SURVEY

In the bridge abutment area on the Rio Grande floodplain, construction was already well underway at the time of the survey. The area had been heavily disturbed and a large quantity of land fill had been brought in and compacted to form an approach ramp to the bridge. Foundations had been dug and piers were in the final stages of construction. An inspection of this vicinity revealed a large quantity of miscellaneous historic debris; but, because of the thoroughly disturbed nature of the area little could be ascertained from this evidence.

In the area between Zaragoza and Hidalgo Streets the property still had not been acquired by the City of Laredo and the buildings were still occupied by their owners or tenants. All of this property was inspected from the street and due to the heavy accumulation of current culturat materials and the existence of vegetation and buildings, it was impossible to determine the presence or absence of archaeologically significant materials. Several buildings appear to be of mid-nineteenth century vintage, or earlier, and consequently worthy of further investigation from an 
architectural viewpoint. However, since their exteriors had been recently plastered, accurate determinations could not be made without removing this exterior covering. Naturally this was not attempted as these buildings were still being occupied. Four of the principal structures in terms of possible historical significance are located at 710 Grant Street, 713 Lincoln Street, 715 Hidalgo Street, and 711 Zaragoza Street.

In addition, a building at 702 Zaragoza Street bears a Texas state historical marker. This building is in the center of the project and is scheduled for destruction. A visit was made to the owners of this residence, Mr. and Mrs. C. C. Shiner, for the purpose of inspecting the property and obtaining information on the historical significance of the building. It was determined by conversation with the Shiners that the building had been constructed in 1855 and that it had been selected as a historical monument because it represented a particular architectural style that had been deemed worthy of preservation.

\section{CONCLUSIONS AND RECOMMENDATIONS}

The results of this survey are in some aspects inconclusive. The area on the floodplain, in which the bridge abutments are under construction, had already been disturbed and modified by the dumping of fill. Although some historic debris was observed, none of it appeared to have any significance.

In the area between Zaragoza and lidalgo Streets, the survey revealed five historic structures of possible importance; as mentioned earlier, one of these (at 702 Zaragoza) bears a state historical marker. Because not all of the various properties had yet been acquired by the city, and since most of 
the buildings are still occupied, it was extremely difficult to make a comprehensive assessment of resources in the vicinity. Thus, our survey in the area must be regarded as a preliminary one.

We offer the following observations and recommendations regarding the resources in the City of Laredo portion of the Laredo International Bridge II project:

(1) We anticipate no adverse effects on resources on the floodplain area, as no significant cultural remains were observed. Since subsurface construction activities had already been completed by the time the survey was made, we are unable to comment on the possible occurrence of any buried materials in the floodplain. If there are circumstances which necessitate further subsurface disturbance resulting from the bridge construction, the project planners and engineers should arrange to have an archaeologist on hand to observe any such excavations.

(2) The status of the house at 702 Zaragoza Street needs clarification. It bears a state historical marker, and determination of its significance and its fate in terms of the proposed project apparently rests with the Texas Historical Commission and the Texas Historical Preservation Officer, Austin.

(3) Once all properties between Zaragoza and Hidalgo Streets have been acquired by the City of Laredo, and once all tenants (and their belongings) have been removed from the area, this locality should once again be checked by archaeologists and historians. It is simply impossible under present conditions to make a full assessment of possible cultural resources. We have established. the fact that four structures (in addition to the one at 702 Zaragoza) appear to be of mid-nineteenth century vintage. Additionally, 
a final survey should be made of the area prior to construction after the clearing of the locality and demolition of buildings. This ultimate survey would constitute a final check for historic and possible prehistoric resources.

(4) Properties owned by the General Services Administration (GSA) and the Texas Highway Department, and slated for modification because of this proposed project, should also be examined by archaeologists. 
Figure 1. Laredo International Bridge II Project The focus of the present survey was in the area outlined by dashed lines. The nearby San Agustin de Laredo Historic District is also shown. 


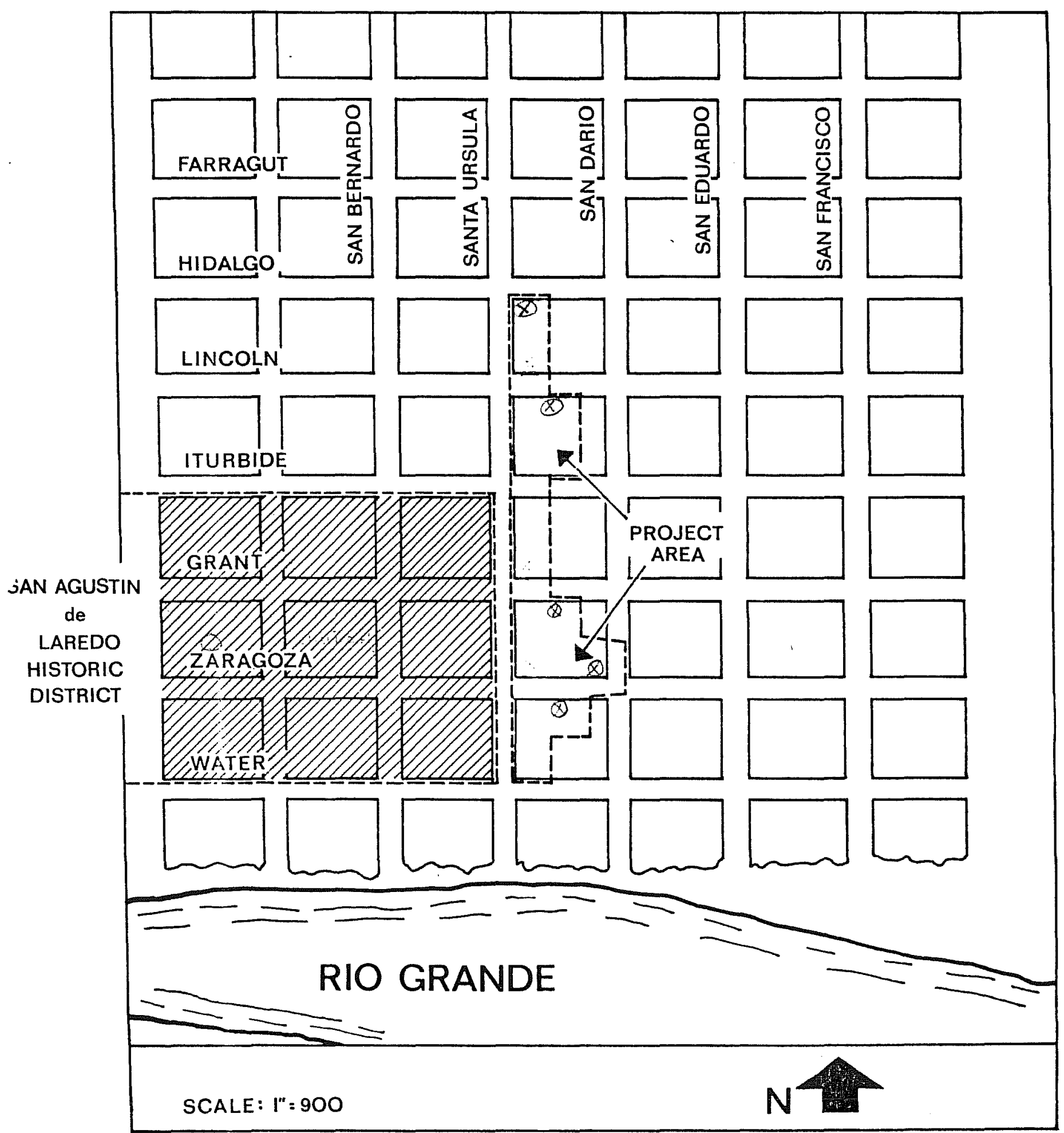


REFERENCES CITED

Benavides, I. M.

1952 Laredo in the Late Spanish and Early American Period. Unpublished M.A. thesis, University of Texas, Austin.

Bolton, H. E.

1915 Texas in the Middle Eighteenth Century: Studies in Spanish Colonial History and Administration. University of California Press, Berkeley.

De Camara, $\mathrm{K}$.

1942 The History of the City of Laredo. Unpublished M. A. thesis, Texas College of Arts and Industries, Kingsville.

Garcia, R. 0 .

1970 Dolores, Revilla and Laredo: Three Sister Settlements. Texian Press, Waco.

HaII, G. D.

1973 Archaeological Survey of Zacate Creek, Webb County, Texas. On file at Texas Archeological Survey, University of Texas, Austin.

Hester, T. R.

1974 On Fluted Points and South Texas Archeology. Texas Archeology 18(2): 11-14.

Hil1, T. C., Jr.

1971 Letter to Dee Ann Story, dealing with archaeological sites on Chacon Creek, Webb County, Texas. On file, Texas 
Archeological Research Laboratory, Austin.

Horgan, Paul

1954 The Great River. The Rio Grande in North American History. Rinehart and Company, New York.

Mitche11, J. L.

1974 An Unfluted Folsom-like Projectile Point from Webb County, Texas. La Tierra 1(2): 9-11.

Peavy, W. G.

1971 Letter dealing with archaeological sites on Chacon Creek, Webb County, Texas. On file, Texas Archeological Research Laboratory, Austin.

Shiner, J. L.

1969 Component Analysis for Archaic Sites. Bulletin of the Texas Archeological Society 40: 215-229.

Vigness, D. M.

1948 The Lower Rio Grande Valley, 1836 - 1846. Unpublished M.A. thesis, University of Texas, Austin.

Walsh, N.

1935 The Founding of Laredo and St. Agustine Church. Unpublished M.A. thesis, University of Texas, Austin.

Webb, W. P. et al.

1952 The Handbook of Texas, Vol. 2: 28. Texas State Historical Association, Austin. 
Wilcox, S.

1938 Laredo during the Texas Republic. Southwestern Historical quarterly $42(2)$.

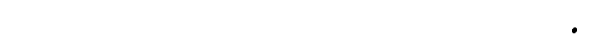

